Стець Н. В. (заступник начальника відділу контролю за відшкодуванням ПДВ ГУ ДФС у Рівненській області, м. Рівне), Стець С. Є., к.т.н., доцент (Національний університет водного господарства та природокористування, м. Рівне)

\title{
УПРАВЛІННЯ ПЕРСОНАЛОМ ЯК СКЛАДОВА СИСТЕМА АГРАРНОГО МЕНЕДЖМЕНТУ
}

У статті висвітлено особливості людського капіталу аграрного сектору України як чинника підвищення конкурентоспроможності. Проаналізовано стан людських ресурсів в сільському господарстві національної економіки. Розглянуто механізми впорядкування системи формування робочої сили, управління розподілом трудових ресурсів, використання персоналу в аграрному секторі. Проведено дослідження світової практики системи управління персоналом для сільськогосподарських підприємств і надана порівняльна оцінка за основними критеріями. Визначені концептуальні засади для побудови адекватної вітчизняної системи управління трудовими ресурсами з врахуванням міжнародного досвіду.

Ключові слова: аграрний менеджмент, людський капітал, конкурентоспроможність, аграрні підприємства, кадровий потенціал.

Вступ. Ефективність аграрного виробництва, конкурентоспроможність продукції на внутрішньому і зовнішньому ринках залежать від рівня забезпечення, використання кадрового потенціалу та застосування науково обґрунтованих методів управління ним. Формування високопрофесійного, стабільного та оптимального збалансованого апарату управління виступає стратегічним завданням кадрової політики як на рівні окремого господарства, так і держави в цілому.

Аналіз останніх досліджень. Помітний внесок у вирішення проблем управління в аграрній сфері економіки і, зокрема, менеджменту, зробили вітчизняні та зарубіжні вчені, що досліджували поняття «менеджмент», «управління» та «аграрний менеджмент», а також проблемні аспекти управління у сфері агробізнесу [2; 3; 7]. Однак більш детального вивчення потребують аспекти підвищення конкурентоспроможності аграрного сектору національної економіки в контексті розвитку людського капіталу.

Постановка завдання. Метою роботи $є$ аналіз людського капіталу аграрного сектору економіки України, вивчення світового досві- 
ду систем управління персоналом та визначення концептуальних засад для побудови адекватної вітчизняної системи управління трудовими ресурсами, на базі механізму впорядкування і удосконалення системи формування робочої сили, збереження, відтворення і покращення трудового потенціалу, управління розподілом трудових ресурсів, використанням персоналу.

Результати досліджень. Проблема ефективного використання наявних обмежених ресурсів все гостріше постає перед виробниками та світовим співтовариством. Поряд із такими основними виробничими ресурсами , як земля, праця, капітал, підприємництво та інформація, менеджмент є ключовим елементом економічної системи будь-якого підприємства і відноситься до ресурсу «праця». Однак це розумова, інтелектуальна праця, яка має прирівнюватися до активів підприємства, тоді як фізична - до витрат.

Термін «менеджмент» (англ. Management) має американське походження і не перекладається на інші мови дослівно. Слово менеджмент є похідним від англійського «to manage», тобто «управляти». 3 розвитком суспільства зміст поняття «менеджмент» трансформувався і увібрав у себе всю різноманітність вимог до управління як мистецтва ведення справ і стилю роботи [1].

Аграрний менеджмент - це особливий прояв менеджменту і може бути визначений як діяльність з організації і координації виробництва в аграрних та інших підприємствах сфери агробізнесу з метою одержання прибутку в довгостроковому періоді, а також досягнення інших специфічних для кожного власника підприємства чи менеджера цілей. Він може розглядатися і як комбінація окремих складових діяльності підприємства: виробництва, комерційної діяльності, фінансів, маркетингу, управління трудовими ресурсами через роботу з людьми. При цьому людський капітал виступає одним із основних якісних факторів економічного зростання секторальної конкурентоспроможності економіки країни.

В аграрному секторі економіки України людський капітал має певні особливості: сезонність використання, важкі умови праці, слабкий розвиток соціальної сфери, недостатній ступінь підготовки, кваліфікації працівників, зростання рівня безробіття; низький рівень оплати праці.

Стан людських ресурсів аграрного сектору національної економіки наведено у табл. $1[4 ; 6]$.

В аграрному секторі економіки у 2017 році було зайнято 2,9 млн осіб, що становить 15,9\% економічно-активного населення України. Простежується тенденція зменшення зайнятого населення у підсекторах підприємств, що спричинено, зокрема, модернізацією 
технологій аграрного виробництва та технічного забезпечення. У 2017 році середньомісячна заробітна плата штатних працівників аграрного сектору економіки становила 3309 грн., а відносно середнього рівня в економіці - 74,6\%.

Відповідно до опитування, проведеного агенцією Agri Survey у квітні 2016 року, 63,0\% власників аграрних підприємств скаржилися на брак кваліфікованих працівників виробничих спеціальностей агрономів, механіків, інженерів, зоотехніків, ветеринарів та ін. Разом із тим, серед студентів та молодих спеціалістів бажання працювати у сільській місцевості майже відсутнє. Лише 16,0\% випускників аграрних вузів висловили готовність до роботи в сільській місцевості. Студенти та молоді спеціалісти пояснюють таку ситуацію пошуком роботи, яка була б цікавою, давала можливість кар'єрного росту та забезпечувала гарантію робочого місця й фінансову стабільність - критерії, які, на їхню думку, досить складно задовольнити [3]. Недивно, що за останні роки частка працівників із повною вищою освітою в аграрному секторі майже не змінилась і становила станом на 2014 рік лише $14,3 \%$ (15,3\% у 2017 р.), хоча загалом в економіці освітньокваліфікаційний потенціал працівників в Україні досить високий.

Так, станом на 31 грудня 2017 року працівники з вищою освітою складали майже 47,3\% облікової кількості штатних працівників економіки України. За деякими видами економічної діяльності працівники з вищою освітою переважають у структурі персоналу, зокрема у сфері фінансової та страхової діяльності - майже 88,0\%; державному управлінні $-85,0 \%$; науці $-80,0 \%$; телекомунікації $-76,0 \%$; освіті - 73,0\% [4].

Зважаючи на це, підвищення конкурентоспроможності аграрного сектору економіки суттєво залежить від рівня розвитку людського капіталу, який виступає його конкурентною прогалиною на цьому етапі розвитку агросектору економіки України.

В зв'язку із зростаючою роллю людського чинника в сучасному аграрному виробництві, однією з найважливіших функцій управління персоналом стає розвиток персоналу, а не просто приведення його чисельності у відповідність до наявності робочих місць, що потребує іншого підходу до прийняття управлінських рішень. Це стало аргументом для виділення управління персоналом в окремий напрямок менеджменту. При цьому цілями управління персоналом підприємства $€$ : підвищення конкурентоспроможності підприємства в ринкових умовах; підвищення ефективності виробництва та праці, а саме досягнення максимального прибутку; забезпечення високої соціальної ефективності функціонування колективу. 
Основні показники стану людських ресурсів аграрного сектору економіки України у 2014-2017 рp.

\begin{tabular}{|c|c|c|c|c|}
\hline \multirow{2}{*}{ Показник } & \multicolumn{4}{|c|}{ Роки } \\
\hline & 2014 & 2015 & 2016 & 2017 \\
\hline Чисельність населення, млн. осіб & 45,6 & 45,4 & 42,9 & 42,7 \\
\hline Частка сільського населення,\% & 31,1 & 31,0 & 30,9 & 30,8 \\
\hline $\begin{array}{c}\text { Природній приріст, скорочення } \\
\text { населення, тис. осіб }\end{array}$ & $-142,4$ & $-158,7$ & $-166,4$ & $-183,0$ \\
\hline У т.ч. у сільській місцевості & $-72,2$ & $-76,4$ & $-78,9$ & $-90,3$ \\
\hline $\begin{array}{c}\text { Економічно активне населення у } \\
\text { віці 15-70 років, тис. }\end{array}$ & 22011,5 & 21980,6 & 19920,9 & 18097,9 \\
\hline Рівень зайнятості населення,\% & 59,7 & 60,3 & 56,6 & 56,7 \\
\hline Рівень безробіття,\% & 7,5 & 7,2 & 9,3 & 9,1 \\
\hline $\begin{array}{c}\text { Зайняте населення аграрного се- } \\
\text { ктору, тис. }\end{array}$ & 3496,0 & 3577,5 & 3091,4 & 2870,6 \\
\hline $\begin{array}{c}\text { У т.ч. наймані працівники підпри- } \\
\text { ємств, установ, тис. }\end{array}$ & 697,8 & 652,1 & 596,0 & 569,4 \\
\hline $\begin{array}{c}\text { Кількість зареєстрованих безробі- } \\
\text { тних в аграрному секторі, тис. }\end{array}$ & 113,4 & 115,0 & 112,6 & 116,4 \\
\hline $\begin{array}{l}\text { Потреба підприємств аграрного } \\
\text { сектору у працівниках для замі- } \\
\text { щення вільних робочих місць, тис }\end{array}$ & 2,5 & 2,3 & 1,6 & 1,2 \\
\hline $\begin{array}{c}\text { Працевлаштовано зареєстрова- } \\
\text { них безробітних за рік в аграрно- } \\
\text { му секторі, тис }\end{array}$ & 137,6 & 138,2 & 132,4 & 130,1 \\
\hline $\begin{array}{c}\text { Частка працівників із повною ви- } \\
\text { щою освітою в аграрному секто- } \\
\text { рі,\% }\end{array}$ & 14,3 & 14,9 & 15,1 & 15,3 \\
\hline $\begin{array}{c}\text { Частка працівників, які підвищи- } \\
\text { ли кваліфікацію в аграрному сек- } \\
\text { торі,\% }\end{array}$ & 1,7 & 1,6 & 1,5 & 1,4 \\
\hline $\begin{array}{c}\text { Частка працівників, які отримують } \\
\text { пенсії,\% }\end{array}$ & 12,2 & 12,5 & 12,4 & 12,3 \\
\hline $\begin{array}{c}\text { Середньомісячна заробітна плата } \\
\text { штатних працівників аграрного } \\
\text { сектору, грн }\end{array}$ & 2086 & 2340 & 2556 & 3309 \\
\hline
\end{tabular}


Успішне виконання поставлених цілей потребує виконання таких задач, як: забезпечення потреби підприємства в робочій силі в необхідній кількості та кваліфікації; досягнення обґрунтованого співвідношення між організаційно-технічною структурою виробничого потенціалу та структурою трудового потенціалу; повне та ефективне використання потенціалу робітника та виробничого потенціалу в цілому; забезпечення умов для високопродуктивної праці, високого рівня ії організованості, вмотивованості, самодисципліни; закріплення робітника на підприємстві, формування стабільного колективу як запорука окупності коштів, що тратяться на робочу силу (залучення, розвиток персоналу); забезпечення реалізації бажань, потреб та інтересів працівників відносно змісту праці, умов праці, виду зайнятості, можливості професійно-кваліфікаційного та посадового просування; узгодження виробничої та соціальних задач (балансування інтересів підприємства та інтересів працівників, економічної та соціальної ефективності); підвищення ефективності управління персоналом, досягнення цілей управління при скороченні витрат на робочу силу [5].

Проаналізуємо світову практику японської, західноєвропейської та американської системи управління персоналом, щоб виокремити ефективні способи та прийоми його формування і використання для сільськогосподарських підприємств (табл. 2).

Провівши порівняльну характеристику закордонних систем управління, можна стверджувати, що існує тісний взаємозв'язок японської системи управління персоналом та системи управління персоналом у малих, середніх та великих вітчизняних фермерських господарствах.

Так, в українських фермерських господарствах та підприємствах Японії спостерігається певна низка спільних рис, таких як: широка спеціалізація працівників, розвиток та підвищення кваліфікації без відриву від виробництва, м'яка форма контролю, присутність «духу сімейності». У фермерських господарствах це пов'язано з діяльністю у таких формуваннях насамперед членів однієї родини та близьких родичів.

Система управління персоналом сільськогосподарських підприємств які входять у холдинги, концерни, корпорації більш приймає риси американської системи. Тут можна виділити такі спільні риси: швидка кар'єра та вузька спеціалізація кадрів; підвищення кваліфікації здійснюється з відривом від виробництва, за спеціальними програмами підготовки; швидке прийняття рішень та повільна їх реалі- 
зація; оцінюються індивідуальні результати праці, їх спільною особливістю $€$ висока корпоративна культура.

Таблиця 2

Порівняльна характеристика систем управління сільськогосподарських підприємств

\begin{tabular}{|c|c|c|c|}
\hline Критерії & \begin{tabular}{|c|} 
Японська система \\
управління персона- \\
лом \\
\end{tabular} & $\begin{array}{c}\text { Західноєвропейська } \\
\text { система управління } \\
\text { персоналом }\end{array}$ & $\begin{array}{l}\text { Американська система } \\
\text { управління персоналом }\end{array}$ \\
\hline $\begin{array}{c}\text { Особливості } \\
\text { підготовки та } \\
\text { навчання } \\
\text { майбутніх ка- } \\
\text { дрів }\end{array}$ & $\begin{array}{l}\text { 1. Початкова шести- } \\
\text { річна школа } \\
\text { 2. Трирічна молодша } \\
\text { середня школа } \\
\text { 3. Старші школи (ко- } \\
\text { леджі, ВНЗ) }\end{array}$ & $\begin{array}{c}\text { 1. Початкова школа } \\
\text { 2. Середня школа } \\
\text { 3. Вища школа (тер- } \\
\text { мін навчання та по- } \\
\text { діли на класи у різ- } \\
\text { них країнах по- } \\
\text { різному) }\end{array}$ & $\begin{array}{l}\text { 1. Молодша школа } \\
\text { (5 років) } \\
\text { 2. Середня школа } \\
\text { (3 роки) } \\
\text { 3. Старша школа } \\
\text { (2 роки) }\end{array}$ \\
\hline $\begin{array}{c}\text { Особливості } \\
\text { трудової дія- } \\
\text { льності }\end{array}$ & $\begin{array}{c}\text { Повільна кар'єра та } \\
\text { широка спеціаліза- } \\
\text { ція кадрів }\end{array}$ & $\begin{array}{c}\text { Швидка кар'єра та } \\
\text { вузька спеціалізація } \\
\text { кадрів }\end{array}$ & $\begin{array}{c}\text { Швидка кар'єра та ву- } \\
\text { зька спеціалізація кад- } \\
\text { рів }\end{array}$ \\
\hline $\begin{array}{c}\text { Набір персо- } \\
\text { налу }\end{array}$ & $\begin{array}{c}\text { Безпосередньо із } \\
\text { навчальних закладів }\end{array}$ & $\begin{array}{c}\text { Здійснюється, в ос- } \\
\text { новному, через аге- } \\
\text { нтства з найму }\end{array}$ & $\begin{array}{c}\text { Зовнішні джерела за- } \\
\text { лучення }\end{array}$ \\
\hline $\begin{array}{c}\text { Розвиток та } \\
\text { підвищення } \\
\text { кваліфікації } \\
\text { персоналу }\end{array}$ & $\begin{array}{c}\text { Без відриву від ви- } \\
\text { робництва, система } \\
\text { безперервного нав- } \\
\text { чання }\end{array}$ & $\begin{array}{c}\text { Концепція навчання } \\
\text { впродовж життя }\end{array}$ & $\begin{array}{c}3 \text { відривом від вироб- } \\
\text { ництва, за спеціальни- } \\
\text { ми програмами підгото- } \\
\text { вки }\end{array}$ \\
\hline $\begin{array}{c}\text { Контроль за } \\
\text { трудовою ді- } \\
\text { яльністю }\end{array}$ & $\begin{array}{c}\text { М'який неформалі- } \\
\text { зований та колекти- } \\
\text { вний контроль }\end{array}$ & $\begin{array}{c}\text { Формалізована, од- } \\
\text { нак м'яка процедура } \\
\text { контролю та індиві- } \\
\text { дуальний і груповий } \\
\text { контроль }\end{array}$ & $\begin{array}{c}\text { Чітко формалізована } \\
\text { жорстка процедура ко- } \\
\text { нтролю та індивідуаль- } \\
\text { ний контроль з боку ке- } \\
\text { рівництва }\end{array}$ \\
\hline $\begin{array}{c}\text { Характер } \\
\text { прийняття } \\
\text { рішень }\end{array}$ & $\begin{array}{c}\text { Повільне прийняття } \\
\text { рішень та швидка їх } \\
\text { реалізація }\end{array}$ & $\begin{array}{c}\text { Широке прийняття } \\
\text { рішень та швидка їх } \\
\text { реалізація }\end{array}$ & $\begin{array}{c}\text { Швидке прийняття рі- } \\
\text { шень та повільна їх ре- } \\
\text { алізація }\end{array}$ \\
\hline $\begin{array}{l}\text { Оцінка пер- } \\
\text { соналу }\end{array}$ & $\mid \begin{array}{c}\text { Оцінюється колекти- } \\
\text { вна праця та колек- } \\
\text { тивна трудова дія- } \\
\text { льність }\end{array}$ & $\begin{array}{c}\text { Оцінюються як коле- } \\
\text { ктивні, так і індиві- } \\
\text { дуальні результати } \\
\text { праці }\end{array}$ & $\begin{array}{c}\text { Оцінюються індивідуа- } \\
\text { льна праця та результа- } \\
\text { ти індивідуальної тру- } \\
\text { дової діяльності }\end{array}$ \\
\hline Оплата праці & $\begin{array}{l}\text { Оплата праці за ста- } \\
\text { жем та за груповими } \\
\text { показниками роботи }\end{array}$ & $\begin{array}{c}\text { Оплата праці зале- } \\
\text { жить від професійно- } \\
\text { кваліфікаційного рі- } \\
\text { вня фахівця }\end{array}$ & $\begin{array}{c}\text { Оплата праці за індиві- } \\
\text { дуальними досягнен- } \\
\text { нями }\end{array}$ \\
\hline
\end{tabular}


продовження табл. 2

\begin{tabular}{|c|c|c|c|}
\hline $\begin{array}{l}\text { Мотивація } \\
\text { персоналу }\end{array}$ & $\begin{array}{c}\text { Грошові винагороди, } \\
\text { оплата за проїзд, по- } \\
\text { зики на купівлю жит- } \\
\text { ла }\end{array}$ & \begin{tabular}{|c|} 
Премії залежно від \\
індивідуальних ре- \\
зультатів праці та від \\
прибутковості підп- \\
риємства, участь у \\
прибутках фірми
\end{tabular} & $\begin{array}{l}\text { Оцінюються індивідуа- } \\
\text { льні результати праці }\end{array}$ \\
\hline $\begin{array}{c}\text { Основна осо- } \\
\text { бливість }\end{array}$ & $\begin{array}{c}\text { Працівники проник- } \\
\text { нуті «духом сімейно- } \\
\text { сті» }\end{array}$ & $\begin{array}{c}\text { Висока мобільність } \\
\text { працівників }\end{array}$ & $\begin{array}{c}\text { Висока корпоративна } \\
\text { культура }\end{array}$ \\
\hline
\end{tabular}

Джерело: систематизовано автором на основі [7].

Для приватних сільськогосподарських підприємств, виробничих кооперативів та господарських товариств схожі особливості формування та використання персоналу з загальноєвропейською системою, а саме: швидка кар'єра; формалізована, однак м'яка процедура контролю та індивідуальний і груповий контроль; швидке прийняття рішень; оплата праці залежить від професійно-кваліфікаційного рівня фахівця; премії виплачуються залежно від індивідуальних результатів праці та від прибутковості підприємства, практикується участь у прибутках фірми, а також висока мобільність кадрів.

Висновки. Аналіз основних показників стану людського капіталу аграрного сектора свідчать про зниження відтворюваності трудових ресурсів. Таким чином, сучасний стан розвитку ринкових відносин в аграрному секторі вимагає адекватної системи управління трудовими ресурсами, на базі механізму впорядкування і удосконалення системи формування робочої сили, збереження, відтворення і покращення трудового потенціалу, управління розподілом трудових ресурсів, використанням персоналу.

Дослідження світової практики японської, західноєвропейської та американської системи управління персоналом, дозволило виокремити ефективні способи та прийоми його формування і використання для сільськогосподарських підприємств.

Крім того, встановлено, що українським сільськогосподарським підприємствам відповідно до схожих особливостей формування і використання своїх працівників прийнятна для наслідування певна історично сформована у світовій практиці система управління персоналом: або японська, або західноєвропейська, або американська. Такий досвід необхідно врахувати вітчизняним підприємствам, що дозволить їм бути більш конкурентоспроможними на світовому ринку, забезпечити високу зайнятість та досягнути високих економічних показників. 
Серія «Економічні науки»

Випуск 3(83) 2018 p.

1. Енциклопедичний словник бізнесмена: менеджмент, маркетинг, інформатика / під ред. М. І. Молдаванова. К., 2013. С. 476-481. 2. Запухляк В. М., Мельник О. І. Людський капітал як чинник підвищення конкурентоспроможності аграрного сектору економіки України. Агросвіт. 2017. № 3. С. 40-44. 3. УКАБ. Ведення аграрного бізнесу в Україні 2015. Український клуб аграрHOГO

бізнесу.

URL: http://ucab.ua/files/Survey/Doing/Doing_2015_ukr_web.pdf (дата звернення: 15.01.2019). 4. Праця України у 2017 році. Статистичний збірник. К. : Державна служба статистики України, 2017. URL: www.ukrstat.gov.ua/druk/publicat/Arhiv_u/11/Arch_pu_zb.htm (дата звернення: 15.01.2019). 336 с. 5. Ковальов Г. Д. Інноваційні комунікації. Персонал. 2000. № 8. С. 14-19. 6. Сільське господарство України за 2008-2017 рік. Статистичний збірник. Державна служба статистики України. URL: https://ukrstat.org/uk/druk/publicat/Arhiv_u/07/Arch_sg_zb.htm (дата звернення: 15.01.2019). 7. Воскобійник С. Я. Порівняльна характеристика різних систем управління персоналу. Modern economics. 2018. № 10. С. 29-35. URL: http://nbuv.gov.ua/UJRN/modecon_2018_10_7. (дата звернення: 15.01.2019).

\section{REFERENCES:}

1. Entsyklopedychnyi slovnyk biznesmena: menedzhment, marketynh, informatyka / pid red. M. I. Moldavanova. K., 2013. S. 476-481. 2. Zapukhliak V. M., Melnyk $0 . \quad$ I. Liudskyi kapital yak chynnyk pidvyshchennia konkurentospromozhnosti ahrarnoho sektoru ekonomiky Ukrainy. Ahrosvit. 2017. № 3. S. 40-44. 3. UKAB. Vedennia ahrarnoho biznesu v Ukraini 2015. Ukrainskyi klub ahrarnoho biznesu. URL: http://ucab.ua/files/Survey/Doing/Doing_2015_ukr_web.pdf (data zvernennia: 15.01.2019). 4. Pratsia Ukrainy u 2017 rotsi. Statystychnyi zbirnyk. K. : Derzhavna sluzhba statystyky Ukrainy, 2017. URL: www.ukrstat.gov.ua/druk/publicat/Arhiv_u/11/Arch_pu_zb.htm (data zvernennia: 15.01.2019). 336 s. 5. Kovalov H. D. Innovatsiini komunikatsii. Personal. 2000. № 8. S. 14-19. 6. Silske hospodarstvo Ukrainy za 2008-2017 rik. Statystychnyi zbirnyk. Derzhavna sluzhba statystyky Ukrainy. URL: https://ukrstat.org/uk/druk/publicat/Arhiv_u/07/Arch_sg_zb.htm (data zvernennia: 15.01.2019). 7. Voskobiinyk S. Ya. Porivnialna kharakterystyka riznykh system upravlinnia personalu. Modern economics. 2018. № 10. S. 29-35. URL: http://nbuv.gov.ua/UJRN/modecon_2018_10_7. (data zvernennia: 15.01.2019).

Рецензент: д.е.н., проф. Сазонець І. Л. (НУВГП)

Stets N. V. (Deputy Head of the Department of Control Over VAT Refunds of the DPS DFS in the Rivne Region, Rivne), Stets S. Y., Candidate of Engineering (Ph.D.), Associate Professor (National University of Water and Environmental Engineering, Rivne)

PERSONNEL MANAGEMENT AS A COMPLEX AGRICULTURAL 


\section{MANAGEMENT SYSTEM}

The peculiarities of human capital in the agricultural sector of Ukraine are presented as a factor of increasing the competitiveness in this article. The state of human resources in agriculture of the national economy is analyzed. Such mechanisms, as streamlining of the labor force formation system, management of the distribution of labor resources, and the use of personnel in the agricultural sector are considered. The study of the world practice for the personnel management system at agricultural enterprises was conducted and a comparative assessment on the main criteria is provided. The conceptual foundations for the construction of an adequate management system of domestic labor resources are defined, taking into account international experience.

Keywords: agrarian management, human capital, competitiveness, agrarian enterprises, personnel potential.

Стець Н. В. (заместитель начальника отдела контроля за возмещением НДС ГУ ДФС в Ровенской области, г. Ровно), Стець С. Е., к.т.н., доцент (Национальный университет водного хозяйства и природопользования, г. Ровно)

\section{УПРАВЛЕНИЕ ПЕРСОНАЛОМ КАК СОСТАВЛЯЮЩАЯ СИСТЕМА АГРАРНОГО МЕНЕДЖМЕНТА}

В статье освещены особенности человеческого капитала аграрного сектора Украины как фактора повышения конкурентоспособности. Проанализировано состояние человеческих ресурсов в сельском хозяйстве национальной экономики. Рассмотрены механизмы упорядочения системы формирования рабочей силы, управления распределением трудовых ресурсов, использования персонала в аграрном секторе. Проведено исследование мировой практики управления персоналом для сельскохозяйственных предприятий и предоставлена сравнительная оценка по основным критериям. Определены концептуальные основы для построения адекватной отечественной системы управления персоналом с учетом международного опыта.

Ключевые слова: аграрный менеджмент, человеческий капитал, конкурентоспособность, аграрные предприятия, кадровый потенциал. 